\title{
Experimental modelling of evaporation and boiling processes in a two-phase thermosyphon
}

\author{
Konstantin Ponomarev ${ }^{1, *}$, Siddharth Raj Gupta ${ }^{2}$, Evgeniya Orlova ${ }^{1}$, and Dmitry \\ Feoktistov $^{1}$ \\ ${ }^{1}$ National Research Tomsk Polytechnic University, 634050 Tomsk, Russia \\ ${ }^{2}$ Indian Institute of Technology Kanpur, Kanpur, India
}

\begin{abstract}
A model of a closed two-phase thermosyphon was developed to study thermo-physical processes in a thermosyphon thermal condition systems of energy-saturated equipment. This model differs from the known by reasoned choice of thermocouples installation providing sealing the device during operation. In addition, the program VI (Virtual Instrument) was created in graphical environment Labview for registration of the temperatures and pressure in the thermosyphon.
\end{abstract}

\section{Introduction}

A decrease in the heat losses, an increase in the efficiency of the heat exchange equipment and supply of safety operation of the technological installations are relevant problems of power engineering $[1,2]$. One of the solutions is to apply -the passive cooling systems of thermally loaded elements based on two-phase thermosyphons [3, 4]. These devices have variety of advantages (independence, ease, availability, high heat-transfer coefficient) compared with traditional cooling systems [5]. Promising ways of increasing efficiency of the thermosyphons are intensification of the boiling processes [6], turbulization of flows [7], coating of the definite structure on inside wall of thermosyphon [8], for example, by laser emission [9] or plasma [10]. Thermosyphons are not widely used in industry due to the absence of scientific -bases of their design and construction.

The aim of this work is to develop the experimental model of a closed two-phase thermosyphon for studying thermo-physical processes in a thermosyphon thermal condition systems of energy-saturated equipment.

\section{Experimental technique}

In experimental model of the thermosyphon, 15 thermocouples TT type $\mathrm{K}$ by OMEGA with diameter of the junction of $130 \mu \mathrm{m}$ were used. For eleven of them, holes $(\mathrm{d}=1.5 \mathrm{~mm})$ were drilled at the bottom and top chamber towards flanged fitting of the copper cylinder of the by the engraver of Sparky MK 135E fixed on the micrometric moving element. Thermocouples were modified for fixed them into the thermosyphon. In order to avoid the

\footnotetext{
Corresponding author: kop.tpu@gmail.com
} 
condensate movement from the vapor channel along the thermocouple housing, the connection of the junction and the housing was treated with heat-resisting silicone sealant. Eleven thermocouples were installed in steel casings with diameter of $1.2 \mathrm{~mm}$ and canned on both sides. The ends of the needles and the wires protruding from them were wrapped by insulated tape to strengthen the developed constructions of needle thermocouples, which were further installed in the thermosyphon (Fig. 1).

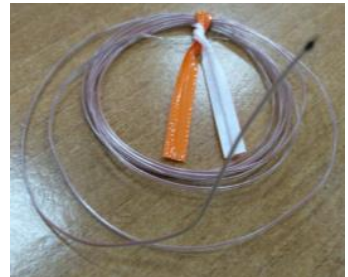

(a)

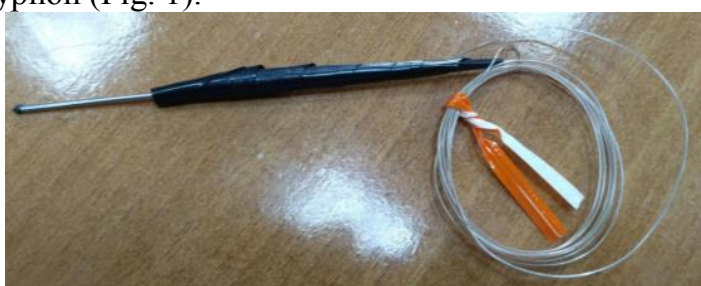

(b)
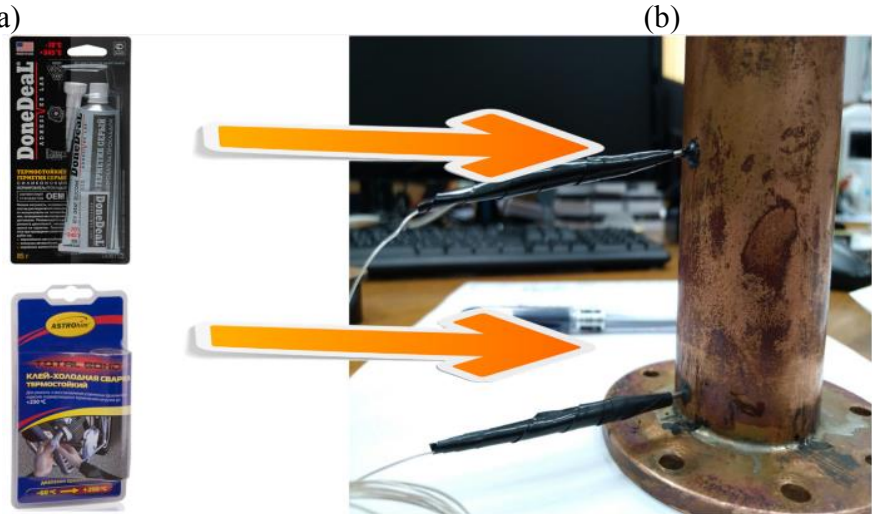

(c)

Fig. 1. Thermocouple before (a) and after (b) modification, thermocouples fixation with sealant and cold welding (c).

The cold welding by Astrohim is found to be preferable for fixing thermocouples into thermosyphon than the sealant by Done Deal, because there was not change of geometric position of the thermocouple due to gravitational forces and applied external forces in time.

Often the vacuum degree of the thermosyphon body does not play a big role, since the thermosyphon successfully works if there is an uncertain volume of air in its cavity. The presence of air results in a partial decrease of the condensation surface and an increase of the initial pressure. The higher the working pressure in the thermosyphon, the air will fill less volume. When the heat transfer characteristics of thermosyphons are under research, a vacuum $\left(6.6 \times 10^{-3} \mathrm{~Pa}\right)$ is especially necessary in studying the condensation process, since even a small amount of air can decrease the heat-transfer coefficient from steam to the thermosyphon wall. Since the experimental model of the thermosyphon was developed to study the processes of boiling and evaporation, vacuum was not created in the cavity of the thermosyphon.

The conditions for the end-to-end supply of heat to the thermosyphon were adopted. These conditions are close to real, when the thermosyphons are installed directly on the heat-loaded elements. The source of heat was a flat silicone heater $(51 \mathrm{~mm}$ x $51 \mathrm{~mm})$ with an operating temperature in the range from -60 to $+250{ }^{\circ} \mathrm{C}$ (maximum short-term temperature is $+300{ }^{\circ} \mathrm{C}$ ) (Fig. 2 (a)).

Using the thermal imaging camera by TESTO (with an error of no more than $2 \%$ in the temperature range from 0 to $+350{ }^{\circ} \mathrm{C}$ ), the temperature field of the heating element was measured (Fig. 2 (b)). It was established that the heating element is heated uniform, the 
exceptions are the edges of the heater due to the technical design of the heating element (Fig. 2 (c)).

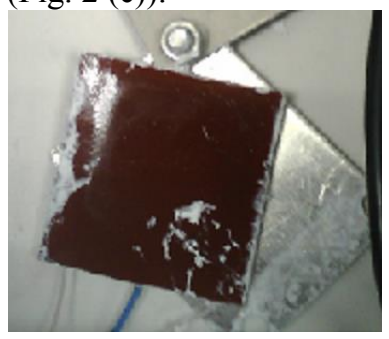

(a)

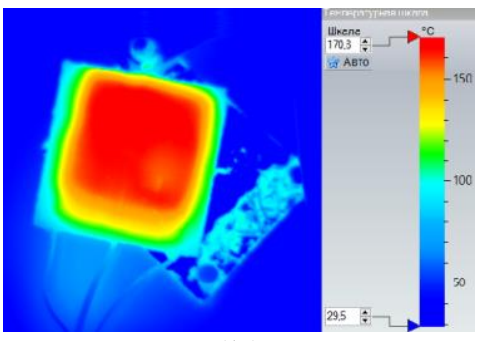

(b)

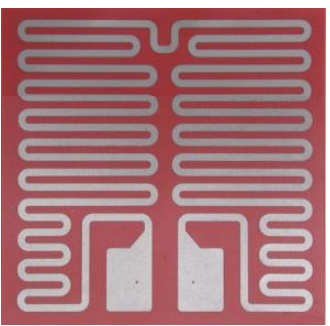

(c)

Fig. 2. Silicon heater: photo (a), thermogram (b), etched heating element (c).

The silicone heater is located between two aluminum plates, fastened with four bolts. The bottom and lateral sides of the heating cell are thermally insulated with a foam rubber by Rockwool. Operating temperature is in the range from -180 to $+550{ }^{\circ} \mathrm{C}$. Thermal conductivity of the foam rubber at room temperature is $0.04 \mathrm{~W} /(\mathrm{m} \cdot \mathrm{K})$. The external frame is made of foamed polystyrene by POLPAN. Operating temperature is in the range from 50 to $+75^{\circ} \mathrm{C}$, thermal conductivity is $0.03 \mathrm{~W} /(\mathrm{m} \cdot \mathrm{K})$ (Fig.3 (a)). Two copper substrates and a thermosyphon were installed on the heating cell. In each of the sections 1-1, 2-2, 3-3 (Fig.3 (b)), two thermocouples were located, the error of which was 0.1 degrees.

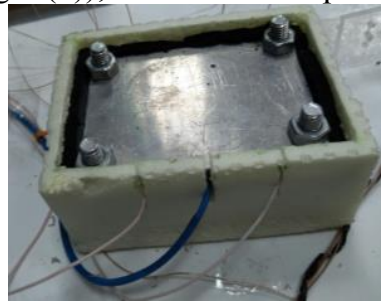

(a)

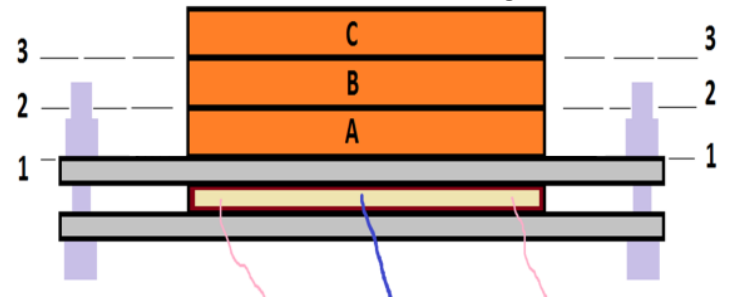

(b)

Fig. 3. Photo of the heating cell (a) and the heating cell diagram (b). A, B - copper substrates, C bottom of the thermosyphon.

Due to poor contact, there were large gaps in the sections, in which the thermocouples were in contact with air. When a load of $80 \mathrm{~V}$ was installed on a laboratory autotransformer, after 5000 seconds, when a quasi-steady operation occurred, the difference between the temperatures recording by thermocouples located in one section $(1-1,2-2,3-3)$ or at different edges of the substrate could exceed 10 degrees. In order to reduce the interaction with air and add stability to the design, the grooves for the thermocouples were cut in the substrate with a depth of $0.6 \mathrm{~mm}$, and a silicon organic thermal paste (KPT 8) was used.

The heat-flux density was calculated according to the Fourier's law:

$$
q=\frac{\Delta T}{(\delta / \lambda)}, W / m^{2}
$$

where $\Delta T$ is the temperature difference between the edges of the substrate, ${ }^{\circ} C ; \delta$ is the thickness of the substrate, $m ; \lambda$ is the thermal conductivity of copper, $W /(m \cdot K)$.

The temperature difference and the heat-flux density (Eq. 1) over the average values of the parameters (for 10 minutes) in the quasi-steady operation are presented in Table 1. 
Table 1. The results of a preliminary series of the experiments.

\begin{tabular}{|l|c|c|}
\hline \multicolumn{1}{|c|}{ Parameters } & $\begin{array}{c}\text { Without } \\
\text { termoconductive } \\
\text { paste }\end{array}$ & $\begin{array}{c}\text { With } \\
\text { termoconductive } \\
\text { paste }\end{array}$ \\
\hline $\begin{array}{l}\text { The difference between the two thermocouples (section 1-1), } \\
\Delta \mathrm{t},{ }^{\circ} \mathrm{C}\end{array}$ & 0.1 & 0.1 \\
\hline $\begin{array}{l}\text { The difference between the two thermocouples (section 2-2), } \\
\Delta \mathrm{t},{ }^{\circ} \mathrm{C}\end{array}$ & 0.2 & 0 \\
\hline $\begin{array}{l}\text { The difference between the two thermocouples (section 3-3), } \\
\Delta \mathrm{t},{ }^{\circ} \mathrm{C}\end{array}$ & 0.4 & 0.2 \\
\hline $\begin{array}{l}\text { The temperature difference between the edges of the first } \\
\text { substrate "A", } \Delta \mathrm{t},{ }^{\circ} \mathrm{C}\end{array}$ & 5.1 & 1.6 \\
\hline $\begin{array}{l}\text { The temperature difference between the edges of the second } \\
\text { substrate "A", } \Delta \mathrm{t},{ }^{\circ} \mathrm{C}\end{array}$ & 5.0 & 1.3 \\
\hline Heat flux density through the first substrate "A", q, MW/m ${ }^{2}$ & 0.47 & 0.15 \\
\hline Heat flux density through the second substrate "B", q, MW/m ${ }^{2}$ & 0.43 & 0.11 \\
\hline $\begin{array}{l}\text { The difference between the heat-flux density (heat losses), } \Delta \mathrm{q}, \\
\mathrm{MW} / \mathrm{m}^{2}\end{array}$ & 0.04 & 0.04 \\
\hline
\end{tabular}

According to the analysis of Table 1, the difference between the two thermocouples installed without the use of termoconductive paste located in the one section in the groove was less than half a degree, but exceeded the error of the thermocouples. The temperature difference between the edges of the substrates decreased twofold and was approximately 5 ${ }^{\circ} \mathrm{C}$.

After applying termoconductive paste with the thermal conductivity of more than of air $\left(\lambda_{m}=1 \mathrm{~W} /(\mathrm{m} \cdot \mathrm{K})>\lambda_{a}=0.027 \mathrm{~W} /(\mathrm{m} \cdot \mathrm{K})\right)$, the difference between the two thermocouples in two of the three sections did not exceed their error. The temperature difference between the edges in the substrates decreased more than three times. Despite this fact, the heat flux density through the substrates was 150 and $110 \mathrm{~kW} / \mathrm{m}^{2}$. And according to the Joule-Lenz's law it is $9.6 \mathrm{~kW} / \mathrm{m}^{2}$.

It is established that when using termoconductive paste, the measurement error is less than without it. However, it was not possible to approach the ideal contact between the two substrates, that is why the heat-flux density input to the bottom of the thermosyphon was determined according to the Joule-Lenz law, taking into account the $15 \%$ loss to the environment:

$$
q=0.85 \cdot \frac{U \cdot I}{S}, W / m^{2}
$$

where $U$ is voltage, $V ; I$ is current, $A ; S$ is internal area of the cross-section of the thermosyphon, $m^{2}$.

To record the temperatures and pressure, the VI program (Virtual Instrument) was developed in the LabView graphical environment.

By setting the input voltage and internal diameter of the thermosyphon in the program, the power supplied to the heating element and the heat-flux density were determined. Calibration of the thermocouples was carried out in the developed program which allows recording temperatures and pressure in the thermosyphon.

The developed experimental model of the closed two-phase thermosyphon with heat removal from the local heat source through the lower cover of the heat exchanger is shown in Fig. 4. 


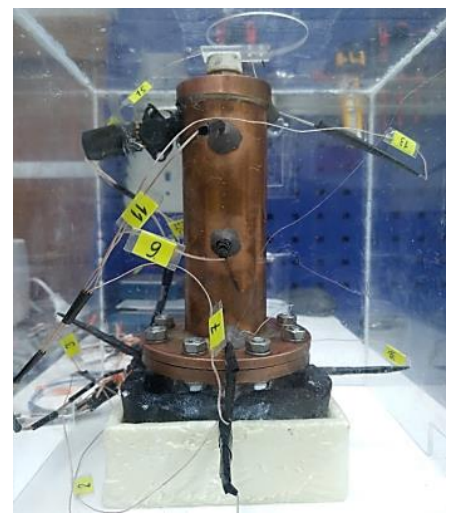

Fig. 4. Photo of the experimental setup.

\section{Conclusion}

An experimental model of a closed two-phase thermosyphon with heat removal from a local heat source through the lower cover of the heat exchange device was developed to study the efficiency of such cooling systems. The cold welding is found to be preferable for fixing thermocouples in the thermosyphon than a sealant. It is established that when using termoconductive paste, the error in measuring the temperature is less than without it. The heat-flux density input to the bottom of the thermosyphon is more accurately determined according to the Joule-Lenz law, taking into account losses of $15 \%$ to the environment than to the Fourier law.

The reported research was supported by Russian Federation President Grant for state support of the Russian Federation leading scientific schools SS-7538.2016.8 (No.14.Y31.16.7538-SS).

\section{References}

1. D. Glushkov, G. Kuznetsov, P. Strizhak, Math. Prob. Eng., 2014, 920480 (2014), DOI: 10.1155/2014/920480

2. S. Juengjaroennirachon, N. Pratinthong, P. Namprakai, T. Suparos, J. Mech. Sc. Tech., 31, 1 (2017), DOI: 10.1007/s12206-016-1241-Z

3. O. Kabov, E. Chinnov, Journal of Enhanced Heat Transfer, 9, 2 (2002), DOI: 10.1615/JEnhHeatTransf.v9.i2.10

4. D. Feoktistov, E. Vympin, A. Nurpeiis, MATEC Web of Conferences, 72, 01081 (2016), DOI: 10.1051/matecconf/20167201081

5. K. Ponomarev, E. Orlova, A. Nurpeiis, MATEC Web of Conferences, 110, 01062 (2017), DOI: 10.1051/matecconf/201711001062

6. V. Nakoryakov, S. Misyura, J. Eng. Thermophys., 25, 1 (2016), DOI: 10.1134/S1810232816010033

7. V. Lebedev, V. Lemanov, S. Misyura, V. Terekhov, Fluid dynamics, 28, 5 (1993), DOI: 10.1007/BF01050044

8. S. Misyura, Applied Thermal Engineering, 113, 472-480 (2017), DOI: 10.1016/j.applthermaleng.2016.11.072 
9. K. Batishcheva, D. Feoktistov, Y. Shanenkova, E. Kirichenko, MATEC Web of Conferences, 110, 01013 (2017), DOI: 10.1051/matecconf/201711001013

10. A. Sivkov, A. Pak, D. Nikitin, I. Rakhmatullin, I. Shanenkov, Nanotechnol. $\quad$ Russ., $\quad \mathbf{8}, \quad 7-8 \quad$ (2013), $\quad$ DOI: $10.1134 /$ S1995078013040174 